\title{
THE TEMPORAL PERSPECTIVE IN HIGHER EDUCATION LEARNERS: COMPARISONS BETWEEN ONLINE AND ONSITE LEARNING
}

\author{
Margarida Romero[margarida.romero@fse.ulaval.ca], Université Laval, Canada, \\ Mireia Usart[mireia.usar@esade.edu], ESADE, Av. de Pedralbes, 60-62 E-08034 Barcelona, Spain
}

\begin{abstract}
Higher Education increases flexibility with online learning solutions. Nevertheless, dropout rates in online university are large. Among the reasons, one aspect deserving further study is students' Time Perspective (TP), which has been studied in onsite HE. It is necessary to know the TP profile of the growing population of online students, and consider its relation with students' preference and convenience factors for choosing online or onsite contexts. In this study, learners' TP in an online and an onsite Catalan HE institutions are compared. Results show that HE students present a high future orientation in general, while online students showed a higher orientation to past negativism. Basic guides are given to help institutions and students in the choice of the better suited learning context according to their TP.
\end{abstract}

Keywords: Online learning, Distance education, Lifelong Learning, Temporal Perspectives, Drop out, Higher Education

\section{Introduction}

Higher Education (HE), in general, and online distance education, specifically, advanced considerably in the final decades of the last century (Bates, 2004). According to Siemens and Matheos (2012) the growth of the social and participative web creates new technological and social change pressures in HE institutions that should adapt to "globalization, expansion, and economic uncertainty, overlaid by emerging technologies that enable the technologically savvy student body to interact in new ways with content and with each other" (para. 3). Modern society demands that citizens become lifelong learners and adapt to the ever-changing labour market. The progression of online learning has introduced a new source of diversity among students (Gallagher, 2007). However, there is a high dropout rate in distance education (Yukselturk, Ozekes \& Türel, 2014) that makes necessary to establish the characteristics of the online HE student profile in comparison with onsite students who follow traditional onsite programs. Research on general demographic differences has identified several online learner characteristics such as the fact that they tend to be mature, have professional responsibilities, and little available time (Paechter \& Maier, 2010; Palloff \& Pratt, 2003). Nevertheless, a study of the intrapsychological factors that differentiate onsite and online learners has not been developed sufficiently to understand why students succeed or dropout. This paper aims to analyse one of the main intrapsychological factors influencing learning, the temporal perspective (TP), defined by Zimbardo, Keough and Boyd (1997, p.1008) as 'the manner in which individuals, and cultures, partition the flow of human experience into distinct temporal categories of past, present and future'. From this definition, TP is an individual difference that has been previously related with age, learning performance and completion of studies (Zimbardo \& Boyd, 1999) in onsite learning 
settings. TP is an important factor to consider in online learning because of its influence in the learning process and outcomes. Online students must self-regulate their temporal flexibility for learning. However, there has been no previous research on the online context, which results in a lack of knowledge about online student TP profiles. No previous studies have focused on the differing profiles of students in onsite and online universities. To assess online student TPs in relation to their onsite counterparts, this paper considers two main HE models - onsite and online universities. Onsite universities require that students attend lectures and classes, while online universities allow greater flexibility in terms of time and space and offer distance-based activities supported through a Computer Learning Environment (CLE).

Main factors involved in the student choice of onsite or online modalities are reviewed, before introducing specific challenges in these contexts.

\section{Convenience and profile based choices of onsite and online HE}

Universities need to rethink their models to adapt to a larger typology of students. In particular, there should be an adjustment of the space and time settings according to the challenges facing lifelong learners. Choosing between onsite and online modalities depends on various factors. When the learner has equal accessibility possibilities to onsite and online HE programs, she could decide the modality to enrol according to her preferences or learner profile, including her temporal orientations as a person oriented to the future or preferring enjoy the present moment. Nevertheless, the equality of opportunities to enrol onsite or online HE is not the same for all potential learners aiming to join a HE program, which could not limit their decision making to their preferences and learner's profile but are limited in their choices by professional, family, location, and temporal constraints. In this paper, we differentiate between the factors related to convenience and factors related to student profiles (preferences). Firstly, in terms of convenience, online learning enables adult learners to study despite professional, family, location, and time constraints. However, when enrolling in online studies because of convenience, adult learners are not primarily choosing this modality according to their TP profile - and could therefore engage in a learning context that does not match their intrapsychological time profile. Secondly, with respect to a preference-based decision, adult learners choose an online learning modality because of their profile as students. In this second case, adult students with a certain temporal orientation (e.g. future orientation) may prefer an online modality. It may be critical to establish this orientation in advance in order to better understand the online student profile.

\section{Convenience factors}

Many online learners enrol in a virtual campus because they cannot attend traditional HE programs for various reasons. In the literature, studies on HE students' choices regarding online or onsite courses have focused on two types of students. Firstly, there is research on onsite students who were offered the option to study online during the research period (Harrington \& Loffredo, 2010; Varela, Cater III \& Michel, 2012). Secondly, other authors focus on students who are directly involved in blended and online learning courses (Paechter \& Maier, 2010) and compare these students to the literature on onsite students. However, there is a lack of studies comparing and analysing the profile and convenience factors of students engaged in differing onsite/online contexts. Analysing the existing literature, there are many convenience factors that could be involved in deciding between onsite and online institutions. Daugherty and Funke (1998) surveyed online students and results showed factors such as: the convenience of completing coursework at home; study times that adjusted to family activities; and access to a larger amount of information and interactivity via the internet. Koons (2012) indicated that students who were unable to attend college and whose promotion at work depended on a college 
education were also obliged to enrol for online classes. Harrington and Loffredo (2010) studied women on online courses and showed that convenience is related to distance; online classes are more accessible to students who would otherwise have far to travel (Swan et al., 2000). Furthermore, another factor related to the choice of online learning is the need for schedule flexibility (Northrup, 2002; Young \& Norgard, 2006), especially for students with work and family obligations (Kim, Welch \& Nam, 2012). Karber (2003) and Deal III (2002) point to the fact that some distance learners do not have time to attend onsite classes because they are working parents with limited free time.

Based on this brief review, we could draw a typical profile of those students who study online for convenience: they are mature, have work and family responsibilities, and are probably far from an onsite campus. However, some young traditional undergraduate students aim to enrol in online courses because of their preferences. Previous research has demonstrated that students who choose to take online courses may differ from their more traditional peers in relation to efficacy, knowledge, and competence for online learning (e.g., Clayton, Blumberg \& Auld, 2010). Thus, students who could attend either onsite or online courses and are without temporal, spatial, family, or work limitations could decide between these options based on their preferences or profile. In the following section we explain the factors related to these profiles.

\section{Preference factors}

There are various studies focusing on student personality traits related to choosing online courses. Harrington and Loffredo's (2010) study showed that the majority of introverts prefer online courses; while extroverts tended to prefer onsite classes. The authors also highlight that students may prefer online courses because they enjoy computer technology and innovation. Students preferring onsite classes were influenced by their need to learn through listening to a lecturer and so better understanding any emotional content. Diaz and Cartnal (1999) compared an onsite and online learning context, making the online course design follow a similar methodology to the onsite course and making both equivalents. Results show that online students possess stronger independent learning styles than their onsite counterparts. Paechter and Maier (2010) researched a sample of Australian HE students and showed that some students preferred online courses because the learning pace could be self-regulated and they could study anywhere at any time. Artino (2010) studied onsite student preferences by proposing students to follow an online program. After the course, the author analysed the different personal factors related to the course selection. He identified two main student characteristics related to a preference for online learning: self-efficacy and satisfaction. In the context of online learning, some authors claim that 'low gregariousness and achievement orientation' were required to achieve the learning objectives (Varela, Cater \& Michel, 2012).

Finally, we highlight the fact that students who have already taken a good number of online courses tend to prefer working online and demand more online offerings from their institutions, as Glover and Lewis (2012) show in a study among 152 college students from three universities in the southeast of the USA with ages ranging from 20 to 29. Results show that the main reasons for preferring onsite learning were lack of contact with teachers in online contexts, suggestions of lower course quality, and student involvement in the online courses; compared to the traditional students' assumption of a passive role during the lesson (Favretto, Caramia \& Guardini, 2005). Furthermore, high school learners who have experienced online learning courses tend to prefer online university programs, even if they live near a campus (Pallof \& Pratt, 2003) and highly value the fact that a university offers a virtual campus. Furthermore, students with lower average academic achievements ( $\mathrm{C}$ grades or below) and less studying experience (1-2 years of studying) prefer onsite learning to online or blended models (Žuvic-Butorac, et al., 2011); however, 
evaluation of students' attitudes towards online learning is needed for adequate course design (Paunescu, 2013).

In brief, we could suppose that students who prefer online courses have prior experience in this modality, and are more time effective, self-motivated, and more likely to manage their studies. Younger students with social expectations prefer onsite courses. However, we should be careful with these results because of the stated limitations related to course design and student samples.

\section{HE student challenges on onsite and online programs}

In this section we focus on the challenges that students face in onsite and online programs, and then examine the role of time, in general, and TP in particular.

\section{Onsite university challenges}

An internet-based society is triggering changes within traditional universities (Glenn \& D'Agostino, 2008). The rapidly evolving needs of a population searching for knowledge are leading to global changes in onsite HE (Fillion, et al., 2007; Siemens \& Matheos, 2012). Nevertheless, the adaptation of onsite university models faces various problems including dropout rates. There is a high dropout rate in the majority of the onsite HE institutions, situated between 10\% and 40\% (Diaz, 2002; Clay, Rowland \& Packard, 2009; Oppedissano, 2011). Dropout rates in onsite education have been related to age and work-life balance (Pallof \& Pratt, 2003). In recent decades, a change in the average age of $\mathrm{HE}$ students $\mathrm{Hu}$, Katherine \& Kuh, 2011) has been observed as more mature adult students engage in HE as part of lifelong learning. This need has made adults return to universities in order to take supplementary courses whilst in full-time employment, or during short career breaks (Concannon, Flynn \& Campbell, 2005). Green (1996) observed that more than 40 percent of students enrolled in two- or four-year colleges in the United States are 25 or older. Furthermore, an increasing numbers of mature (aged 21 on admission) and male students are starting undergraduate programs (Kell, 2006). These mature profiles are more focused on the transition from classroom to work and are often eager to apply their knowledge to real world activities. Mature students face difficulties related to age, such as work and family binds, which could be hampering their academic success in traditional onsite HE.

\section{Online university challenges}

Global changes in Higher Education are requiring the use of ICT to reach a broader clientele in onsite and online universities (Altbach, Reisberg \& Rumbley, 2009). Online institutions base their model on the internet and classes are only accessible online. Nevertheless, distance universities have demonstrated, even before the internet, how technology makes it possible to deliver good higher education beyond a physical campus (Volery \& Lord, 2000). In some countries, online universities were created as an extension to the traditional onsite university model; however, fully online universities, such as the Universitat Oberta de Catalunya (UOC) are emerging (Sangrà, 2001). Online education based on web technology faces several challenges - including increased dropout rates (Taniguchi \& Kaufman, 2005) that are related with temporal flexibility and selfregulation (Fillion et al., 2007), as well as problems of student socialisation (Vermeulen \& Schimdt, 2008). These aspects deserve further study.

Online dropout rates are 20\% higher than in onsite institutions (Diaz, 2002; Clay, Rowland \& Packard, 2009). In the US, dropout rates range between 29.5\% (for public associate degree students in US) and $56.1 \%$ on private online bachelor courses (Evans, 2009). Following Mortagy 
and Boghikian-Whitby (2010), online student dropout rates are related to finding the course more demanding and sometimes overwhelming when compared to onsite courses. Other studies in online education suggest low levels of academic locus of control and low metacognitive selfregulation skills (Lee, Choi \& Kim, 2012) lead to dropouts. Furthermore, time is a factor related to most of the research on dropout factors (Cocea \& Weibelzahl, 2011; Lee, Choi \& Kim, 2012). However, while some studies point to a lack of time (Taniguchi \& Kaufman, 2005) and time incompatibilities with professional and family pressures (Jacobs \& King, 2002; Evans, 2009) there is a lack of in-depth analysis of the students' time factors involved in dropouts.

Secondly, and related to dropout rates, current online HE lacks socialisation tools that help students become part of a group. Nevertheless, blended learning combining onsite and online classes do help decrease feeling of isolation (Robai \& Jordan, 2004; Bishop et al. 2007). A challenging aspect is the synchronous (or asynchronous) modality of the activities and learners' time management skills, both individually and when collaborating in online group activities. Students who fail to make friends are likely to withdraw from onsite education (Vermeulen \& Schimdt, 2008).

Finally, and parallel to onsite HE, there are two student profiles in online universities; adult learners (older than 25) with family responsibilities and full-time jobs (Green, 1996; Concannon, Flynn \& Campbell, 2005); and young students who are increasingly engaging in online universities as a first option, probably due to the time flexibility these models promise (Dabbagh, 2005). Nevertheless, this promised flexibility usually requires more self-regulation (Lee, Choi \& Kim, 2012) and more time invested in study (Peetsma, 2000) that directly relates to time management skills and individual temporal perspectives.

\section{Time in HE}

Time is one of the main factors required to understand the learning process in HE. In this section, we analyse the temporal constraints of adult students before focusing on TP as an intrapsychological time factor that should be considered in relation to the success of HE student.

There are a growing number of part-time students (Sursock, \& Smidt, 2010) in onsite and online universities. Onsite universities are implementing elements of e-learning in traditional courses to prepare students for future participation in education (Bonk, 2009). These changes may produce some innovations in the traditional organisation, planning, and management of education (ŽuvicButorac et al., 2011), especially in schedules and temporal models. Online universities use webbased technology to deal with temporal flexibility (Dabbagh, 2005). Online HE can make course material accessible anytime and anywhere (Volery \& Lord, 2000) as a part of the aim to integrate diverse technologies and methodologies for student activities and interaction in both asynchronous and synchronous modes. Online HE flexibility could help adult learners enrol for distance education, who face higher temporal constraints than onsite counterparts (Carnoy et al., 2012).

However, there is a need to analyse the time factor beyond the quantitative perspective, and analyse the intrapsychological temporal factors such TP. Considering the importance of TP in the time factor (as an underlying factor) and individual differences that could mediate in student time management and affect academic performance (Eren, 2009), it is important to characterise the TP of online learners in order to analyse its adequacy with online HE challenges. Although few studies have focused on TP in online HE, we can affirm from research focused on HE in general that present hedonist students (seeking immediate pleasure) are more oriented to social and ICT activities than future oriented learners (desiring to plan and achieve specific future goals) or present fatalist students (feeling powerless about their future no matter what they do) (Zabel, European Journal of Open, Distance and e-Learning - Vol. 17 / No. 1 
1995; Zimbardo \& Boyd, 1999). Considering the relationship of student TPs with age (DíazMorales, 2006; Zimbardo \& Boyd, 1999), self-regulation, and time invested in study, we believe these new scenarios require further study of student TP profiles.

\section{Student TPs}

Time perspective (TP) has historically been defined and measured from a wide range of approaches and using different methods. However, we will focus on the foundational work by Zimbardo, Keough, and Boyd (1997, p.1008), who define a multifaceted, cultural TP as "the manner in which individuals, and cultures, partition the flow of human experience into distinct temporal categories of past, present and future". From this definition, TP can be understood as an individual's cognitive construct, theoretically subdivided into five subscales or factors: present hedonism; present fatalism; past positivism; past negativism; and future time perspective. We briefly introduce each of these five factors in the Table 1.

Table 1: Description of the five TP factors (based on Zimbardo, Keough and Boyd (1997))

\begin{tabular}{|c|c|c|c|c|}
\hline $\begin{array}{l}\text { Past Negative } \\
\text { (PN) }\end{array}$ & $\begin{array}{l}\text { Past Positive } \\
\text { (PP) }\end{array}$ & $\begin{array}{l}\text { Present } \\
\text { Hedonists (PH) }\end{array}$ & $\begin{array}{l}\text { Present Fatalists } \\
\text { (PF) }\end{array}$ & $\begin{array}{l}\text { Future Time } \\
\text { Perspective (FTP) }\end{array}$ \\
\hline $\begin{array}{l}\text { They remember } \\
\text { the traumatic and } \\
\text { negative } \\
\text { experiences from } \\
\text { the past and tend } \\
\text { to over generalize } \\
\text { those for their } \\
\text { entire life. }\end{array}$ & $\begin{array}{l}\text { They tend to } \\
\text { recall the } \\
\text { positive } \\
\text { experiences } \\
\text { from their past. } \\
\text { It is related to an } \\
\text { optimistic } \\
\text { outlook of life. }\end{array}$ & $\begin{array}{l}\text { They are } \\
\text { oriented } \\
\text { towards } \\
\text { immediate } \\
\text { pleasure, living } \\
\text { the present } \\
\text { moment without } \\
\text { worrying too } \\
\text { much about the } \\
\text { future. }\end{array}$ & $\begin{array}{l}\text { They feel } \\
\text { powerless about } \\
\text { their future no } \\
\text { matter what they } \\
\text { do; they perceive } \\
\text { themselves as } \\
\text { helpless and } \\
\text { define life as } \\
\text { unfair. }\end{array}$ & $\begin{array}{l}\text { They desire to plan } \\
\text { and achieve specific } \\
\text { future goals; they } \\
\text { are achievement- } \\
\text { oriented, have } \\
\text { expectations for the } \\
\text { future and hope for } \\
\text { change. }\end{array}$ \\
\hline
\end{tabular}

To measure TP we use the Zimbardo time perspective inventory (ZTPI; Zimbardo \& Boyd, 1999). This instrument consists on 56 items or sentences grouped into five theoretically independent factors corresponding to five time orientations. The instrument contains 10 sentences describing past negative behaviour, 10 measuring past positive behaviour, 8 that operationalise the present fatalist orientation, 15 for present hedonism and, finally, 13 statements on future time perspective. Each statement must be rated using a 5-point Likert scale $(1=$ strongly disagree, and $5=$ totally agree). ZTPI results show a five-dimensional value for an individual's TP. Following Zimbardo and Boyd, individuals usually tend to one or more of the five orientations; and few people have a balanced TP according to the authors of this technique.

A wide range of studies on TP have focused on onsite higher education (Romero \& Usart, 2012). Onsite learning, in general, and HE in particular, have implemented future-oriented educational models. That is, onsite learning activities and goals are most focused on future rewards and prepare students for dealing with delayed gratification (Van der Veen \& Peetsma, 2011). Future orientation is a critical factor for promoting increased proximal motivation in students (Miller \& Brickman, 2004). However, despite online HE being widespread, there is little literature on this learning context. We can affirm that, as indicated in the previous section, the study of TP is relevant in these learning models because institutions are no longer onsite, future-based contexts, but they can also give immediate feedback in web-based activities, synchronic tasks, and selflearning materials. 
As we will further study in the following sections, there are two temporal orientations that could be strongly related to learning: present hedonism (defined as seeking immediate pleasure, with little regard to risk or consequences); and future time perspective or FTP (characterised by delayed gratification as a result of the desire to achieve specific long-term goals). Present-oriented individuals show lower academic achievements when compared to future-oriented students both for onsite and online learning (Malka \& Covington, 2005; Zabel, 1995). Future-oriented individuals tend to engage more than present students in onsite learning activities (Simons, et al., 2004). Nevertheless, we will not focus on these two factors, but examine the relationship between student temporal profiles and each TP factor - for both onsite and online higher education models.

\section{Onsite university student TPs}

Age is one of the student characteristics that are changing in onsite universities. Furthermore, it is one of the variables historically related to TP. Previous studies have shown a higher future orientation among young adults than mature students (Mello \& Worrell, 2006). Since mature lifelong learners are more focused on the present applications of what they learn, these profiles do not present a high FTP when compared to young students, who could need more future orientation in order to foresee the benefits of their efforts (Van der Veen \& Peetsma, 2011).

Fillion, Limayem, Laferrière and Robert (2007) observe various student characteristics (such autonomy, anxiety, and motivation) that can be related to higher educational models. In particular, onsite institutions in the UK require self-directed learning skills, a positive academic self-efficacy, internal academic locus of control, and a positive academic self-concept (Kell, 2006). These individual differences may be requirements for succeeding in modern onsite learning programs. Self-directed learning skills and positive self-efficacy have been related to future TP in onsite HE students (Bosato, 2001; Lens, Simons \& Dewitte, 2001).

Dropout rates among various demographic groups of students differ in many countries (Thomas \& Quinn, 2003) and a greater proportion of mature rather than young students do not continue in onsite higher education after their first year. Dropout rates have also been related to student TPs. Present hedonist undergraduate students show higher dropout rates (Zimbardo \& Boyd, 1999) because they tend not to consider future consequences. Horstmanshof and Zimitat (2007) showed that for first-year onsite undergraduates, future oriented students show a higher academic engagement and, in consequence, higher completion rates. Students who fail to make friends are likely to withdraw from onsite Higher Education learning (Vermeulen \& Schimdt, 2008). Past negative onsite students have unsatisfactory interpersonal relationships, while past positive students show better social relations in educational contexts (Zimbardo \& Boyd, 1999).

Researchers have mainly focused on first-year, onsite students (de Volder \& Lens, 1982; Zimbardo \& Boyd, 1999; Horstmanshof \& Zimitat, 2007). Results from their analysis suggest that students with a high Future TP (FTP) show higher academic achievement; in particular, Horstmanshof and Zimitat measured FTP as a mediating variable in student engagement. Students who are present oriented tend to dropout more often in onsite university courses (Zimbardo \& Boyd, 1999).

Finally, cultural aspects of onsite students have also been related to TP. Fourez (2009) studied 120 impoverished Higher Education students and found a tendency towards present-focused temporal perspective. A study of onsite nursing students in Brazil showed a decreasing number of onsite applications from the same geographical area, and a predominance of unemployed students (Wetterich \& Melo, 2007). Furthermore, students coming from private schools enter university within two years of concluding secondary school. These results can be related to the 
fact that, in general, western cultures are associated with higher FTP, while South American and African cultures are more present hedonist (Zimbardo \& Boyd, 2009).In particular, Bosato (2001) measured 159 first-year university students and found that $25 \%$ of the participants were past fatalists, $19.5 \%$ past positive, $18.9 \%$ were present hedonists, $18.9 \%$ past negative, and finally, $17.6 \%$ were future oriented. The authors (Romero \& Usart, 2012) measured TP for a blendedlearning master's course at ESADE (an onsite university and business school in Spain) and found that $50 \%$ of the students were future oriented; $33 \%$ presented a balanced TP, and only $16.7 \%$ were present oriented.

\section{Online university student TPs}

Online learners described themselves as time-poor (MacGregor, 2000) and points to the lack of time as one of their main difficulties in the HE education (Romero \& Barberà, 2013). Temporal constraints are considered one of the characteristics of the online student profile. Halsne and Gatta (2002, p.1) observed that online student are mostly full-time workers and many "have children and take their online courses late at night, after their children are in bed or early in the morning before work". Not having time to attend onsite classes is one of the major reasons why online learners engage in virtual university courses (Pérez-Cereijo, 2006). In this context, different studies have reported that online learners prefer individual and self-regulated learning activities (Collier \& Morse, 2002; Cuthrell \& Lyon, 2007; Yang \& Tsai, 2008) and there is a strong expectation of flexible time among e-learners (Delfino et al., 2004; Mortagy \& Boghikian-Whitby, 2010).

Research on TP in online learning is sparse. There are few studies on the field of temporal perspective and distance higher education. Zabel (1995) used the first version of the ZTPI to study the TP profile of students on correspondence university courses; a total of 101 adult students were studied ( $M=31.04$ years-old). Results indicate that participants had more of an orientation to the future than the past or present. A second study by Schmidt and Werner (2007) focused on online HE, but did not measure student's TP profiles, it focused on the analysis of the possible designs for future-based online courses.

\section{The present study}

Our aim is to study TP among university students in two Catalan universities. In particular, we focus on the following models: an onsite university with blended-learning models based on onsite classes, and a completely online university. Differences between online and onsite universities will be examined from the standpoint of students' TP. Another variable we take into account is student age - which has previously been outlined as an important factor regarding TP. Results of our study could provide a better knowledge of the differences among online and onsite students and help explain the relationship between TP and age. Understanding the TP profile of the growing population of online students, and using a mix of future and present oriented instruction in online models could offer innovative methods for tackling these challenges (Schmidt \& Werner, 2007).

\section{Research questions}

In the previous sections, it was highlighted that HE models related to university and student characteristics are changing. The observation that onsite students are younger and devote their time to learning more than online students is no longer true. Nevertheless, online learners of all ages must deal with more time constraints, related to self-regulation and active learning (Leidner \& Jarvenpaa, 1995; Fischer, Rohde \& Wulf, 2007). These online students may show a different TP factor distribution than younger, less experienced onsite students (Thomas \& Quinn, 2003). 
As little research has been conducted in this field, in particular for online students, there are no previous patterns or expected results on the TP distribution among the two groups; nevertheless, from the various university and student profiles and age distributions, the following research questions are stated:

- Is onsite and online education suited to learner TPs?

- How can onsite and online education be adapted to learner TPs?

\section{Methodology}

\section{Participants}

A total of 161 participants were retrieved from two different samples. Firstly, 56 students engaged in the Universtitat Autònoma de Barcelona (UAB). Secondly, 105 online students at the Universitat Oberta de Catalunya (UOC) were studied. Online learners (Age M=33.04; SD=10.47) were studying first term of a masters course in teaching and pedagogy, while onsite students (Age $\mathrm{M}=24.02$; $\mathrm{SD}=6.91$ ) were studying a first term course on educational psychology. The sample population for each context has been considered in relation to the profile of onsite HE students (mostly undergraduates) and online HE students (mostly engaged in postgraduate programs as part of their continuous education). Considering the importance of the "first year experience" in a new HE program discussed in the "Student retention in open and distance learning" symposium reported by Gibbs (2003) both of the samples are engaged in their first term courses.

- Onsite learning: the UAB model. The Universitat Autònoma de Barcelona (UAB) was founded in 1968. The founders aimed to establish a traditional model. Nevertheless, this young university now has a bimodal learning model, combining the advantages of classroom learning with the use of information and communication technology (ICT).

- Online learning: the UOC model. The Universitat Oberta de Catalunya (UOC) was created as the first fully online university in Spain in 1995 (Sangrà, 2002). This model started from scratch considering the requirements and opportunities created by the distance education model. The UOC temporal model is mostly asynchronous as it aims for a high level of flexibility for lifelong learning adult students, and pursues online collaboration among all the actors involved in learning. The target population are both mature students (older than 25) and younger students replacing onsite with distance education, and profiles that combine onsite learning activities with distance education programs.

\section{Research techniques}

The Spanish version (Díaz-Morales, 2006) of the ZTPI was used because this version was validated in 756 Spanish adults between 19 and 67 years, the first 5 factors explained a $33.82 \%$ of the variance, and these factors presented the following Cronbach Alpha results: $\alpha=0.80$ for past negative, $\alpha=0.64$ for past positive, $\alpha=0.70$ for present hedonism, $\alpha=0.79$ for present fatalism and $\alpha=0.74$ for future. We used this test among the UAB and UOC students sample described in the previous section in order to study their TP. Researchers distributed the test online using a LimeSurvey for both online and onsite students. Both groups completed the ZTPI at the end of the course after being invited via email.

This test measures an individual's orientation towards the five factors composing TP, where the past, present, and future temporal frames are subdivided into five subscales or factors: present hedonism; present fatalism; past positivism; past negativism; and future time perspective. ZTPI provides researchers with a quantitative value for an individual's TP. 


\section{Results}

Descriptive statistics show that students in the sample have a high score in FTP $(M=3.83$, $\mathrm{SD}=0.41$ ) and past negative factors (SD 0.44; $\mathrm{M}$ 3.68). Present hedonism scoring is lower (SD 0.48 ; M 3.21,), and finally past negative (SD 0.70; M 2.79) and present fatalist show the lowest scores (SD 0.46; M 2.80).

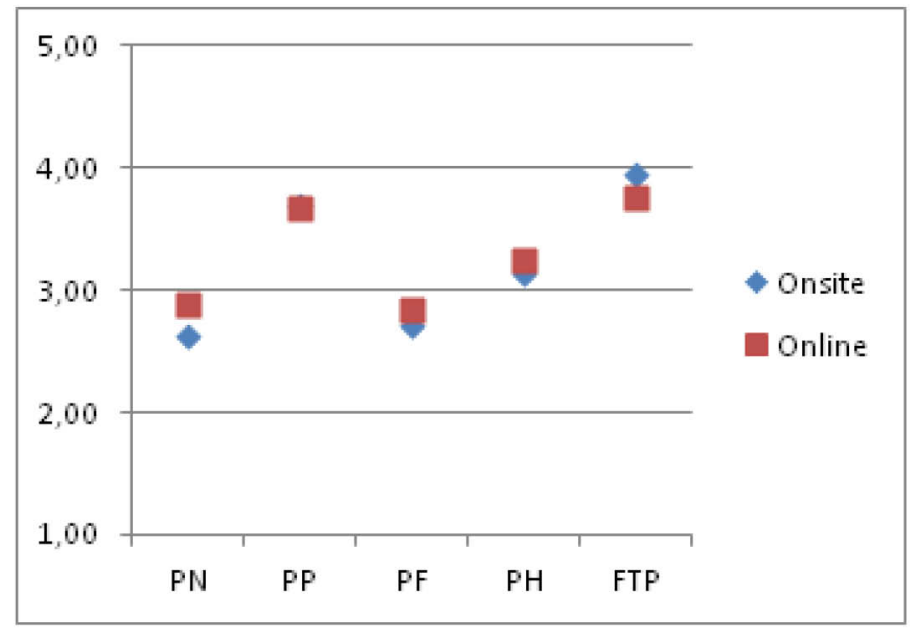

Figure 1. Average TPs for online and onsite students

This profile of temporal perspectives is close to the balanced time perspective (Zimbardo \& Boyd, 1999) that represents an ideal temporal frame for good time management. Secondly, we present the results for the various TP factors and university models (online vs. onsite): scores examined with a one-way ANOVA (at a 95\% level of confidence) revealed no significant differences for the present factors: Present Fatalist (PF) scored similarly in both groups $\mathrm{F}(1,160)$ $=2.512, \mathrm{p}=.115$ and Present Hedonist $(\mathrm{PH})$, with $\mathrm{F}(1,160)=1.368, \mathrm{p}=.244$. Results for past positivism are also insignificant $\mathrm{F}(1,160)=.192, \mathrm{p}=.662$. Past Negative $(\mathrm{PN})$ is significantly higher for online students than onsite students $\mathrm{F}(1,160)=4.568, \mathrm{p}=.034$. Finally, Future Time Perspective (FTP) scores high on average for onsite students when compared to online students $\mathrm{F}(1,160)=7.047, \mathrm{p}=.009$.

Table 2: Average and standard deviations for the five TP factors in relation to type of course

\begin{tabular}{|l|c|c|c|c|}
\hline \multirow{2}{*}{ ZTPI Factor } & \multicolumn{4}{|c|}{ University } \\
\cline { 2 - 5 } & \multicolumn{2}{|c|}{ UOC (online) } & \multicolumn{2}{c|}{ UAB (onsite) } \\
\cline { 2 - 5 } & $\mathbf{M}$ & SD & M & SD \\
\hline Past Negative (PN) & $2.87^{*}$ & 0.72 & $2.63^{*}$ & 0.61 \\
\hline Past Positive (PP) & 3.67 & 0.46 & 3.69 & 0.39 \\
\hline Present Hedonist (PH) & 3.24 & 0.48 & 3.15 & 0.46 \\
\hline Present Fatalist (PF) & 2.84 & 0.46 & 2.72 & 0.45 \\
\hline Future Time Perspective (FTP) & $3.77^{* *}$ & 0.43 & $3.94^{* *}$ & 0.34 \\
\hline
\end{tabular}

${ }^{*} p<0.05 ; * * p<0.01$

To study the differences between age groups and TP, we divided our sample into four age groups. Results can be accessed in Table 3. Two of the five factors composing TP (Past Positive, Past Negative) significantly change with age - as we will discuss in the next section. 
Table 3: Averages and standard deviations for TP factors in student age ranges

\begin{tabular}{|l|l|l|l|}
\hline ZTPI Factor & Age range & $\mathbf{M}$ & SD \\
\hline PN & $18-27$ & 3.01 & .75 \\
\cline { 2 - 4 } & $28-37$ & 2.60 & .55 \\
\cline { 2 - 4 } & $38-47$ & 2.65 & .71 \\
\cline { 2 - 4 } & $48-57$ & 2.57 & .36 \\
\hline PH & $18-27$ & 3.38 & 0.47 \\
\cline { 2 - 4 } & $28-37$ & 3.08 & 0.43 \\
\cline { 2 - 4 } & $38-47$ & 3.03 & 0.45 \\
\cline { 2 - 4 } & $48-57$ & 3.04 & 0.43 \\
\hline FTP & $18-27$ & 3.73 & 0.45 \\
\cline { 2 - 4 } & $28-37$ & 3.89 & 0.31 \\
\cline { 2 - 4 } & $38-47$ & 4.01 & 0.35 \\
\cline { 2 - 4 } & $48-57$ & 3.59 & 0.31 \\
\hline PP & $18-27$ & 3.78 & 0.40 \\
\cline { 2 - 4 } & $28-37$ & 3.69 & 0.46 \\
\cline { 2 - 4 } & $38-47$ & 3.50 & 0.38 \\
\cline { 2 - 4 } & $48-57$ & 3.12 & 0.09 \\
\hline \multirow{5}{*}{ PF } & $18-27$ & 2.89 & 0.41 \\
\cline { 2 - 4 } & $28-37$ & 2.76 & 0.48 \\
\cline { 2 - 4 } & $38-47$ & 2.66 & 0.49 \\
\cline { 2 - 4 } & $48-57$ & 2.63 & 0.47 \\
\hline
\end{tabular}

To study significant age differences, we conducted a Tukey's post-hoc analysis. This test revealed significant results for age ranges and factors; in particular; Past Negative (PN) decreases with age; Past Positivism (PP) also decreases with age but only significantly between the first and last group. Present Fatalism (PF) decreases with age, but this tendency is not significant in our sample of HE students. Present hedonism significantly decreases with age for the first three age groups. Finally, FTP shows a significant rise for the first three age groups, but decreases from the age of 48.

\section{Discussion}

Two research questions guided our study: is onsite and online education adequate according to student TPs? How can onsite and online education be adapted to student TPs? We have studied student TPs in two different HE contexts: onsite and online courses in two Catalan universities. Intrapsychological traits are related to age and personality factors such as introversion, selfefficacy, and learning style (Diaz \& Cartnal, 1999). We expected to find differences in student TP profiles between onsite and online universities. However, students do not only engage in online or onsite courses based on their preference ('what I prefer'), but also on convenience factors ('what I need'). For convenience factors, online learning courses could be a solution for online learners with "children or family responsibilities" as they offer a greater temporal flexibility than onsite learning courses (Sullivan, 2010, p.805). In onsite HE students are together in the classroom and can easily meet up out of the classroom; according to Hiltz and colleagues (2000), social relationships and the sense of the community is usually present on a traditional face-to-face campus. However, the face-to-face model could impose more constraints regarding time on students and may not fit the profile of a lifelong adult learner whose only convenient option is online education. Results from our study show that students in onsite HE have a significantly lower average age (around 24) than online students, who are mostly in their mid-30s. These results are similar to those shown in previous studies (Gilbert, 2001; Pallof \& Pratt, 2003), which 
allows to consider the sample as representative of the population of onsite and online $\mathrm{HE}$ learners in a European context.

Furthermore, student characteristics derived from our results show that students in the online Catalan university (UOC) are older on average than students in the UAB, which is coherent with the online learners' profile observed in previous studies (Jacobs \& King, 2002). Older students are more likely to drop out of onsite universities than younger students (Thomas \& Quinn, 2003), which could be attributed to the conflict with family and work commitments when there is not enough time flexibility, as stated in previous research (Boeren, Nicaise, \& Baert, 2010).

In relation to the TP profile of online and onsite students, results show significant differences in two factors of TP: students taking the online course show a higher Past Negative (PN) factor loading and lower Future TP orientation than onsite learners. These results could be related with the Harrington and Loffredo (2010) study which showed that extroverts such as past positivists tend to prefer onsite classes; this chimes with the results of Simons, Vansteenkiste, Lens and Lacante (2004), which showed that future-oriented individuals tend to engage more in onsite learning activities than present students. Furthermore, previous literature identifies FTP as one of the temporal orientations that could be strongly related to learning (Malka \& Covington, 2005; Zabel, 1995). We propose a further research line focused on this factor of TP to see if the higher FTP profile shown among onsite learners could also be related to higher grades. Students in our sample of onsite and online contexts have a similar orientation towards the present. This result could be related to the fact that present-oriented profiles tend to think less about the consequences of a choice, and these students could enrol in a university course only because of their preferences - and without considering what best suits their needs.

A relevant finding of this study is that the younger adult students in our sample are more past orientated. In particular, their average orientation is past positive rather than past negative. Past positive orientation in $\mathrm{HE}$ learners has not been previously studied and this deserves further research in order to understand its effect on learning outcomes and processes. FTP is higher in younger students than older students in our sample. According to Van der Veen and Peetsma (2011), this reflects the fact that older lifelong students are more focused on the present applications of what they learn; and so may have a low FTP when compared to younger students (who need to be more focused on the future in order to foresee the further benefits of their efforts). The results published by Mello and Worrell (2006) for an HE onsite sample showed that young adult students had a significantly higher future orientation than older adults. Finally, Zabel's (1995) study on TP profile of correspondence HE students also indicates that participants in a distance course were more orientated to the future than the past or present. However, Díaz-Morales (2006) showed that young Spanish adults (between 19 and 29) had a higher present hedonist scoring, while more mature adults showed a higher FTP orientation. This seems to contradict our results for FTP, but we must remember that the Díaz-Morales sample was focused on Spanish population in general; while the higher FTP value in our study is possibly characterised by the fact that adults who enrol in $\mathrm{HE}$ are more likely to delay gratification to obtain specific long-term goals. As Costa and McCrae (2003) show, a higher FTP is expected for middle-age individuals, because there is a tendency for this group to have responsibilities that require planning and anticipation: factors related to future orientation.

After this analysis of the results, we believe there is a need to help identify student needs and preferences related to their TPs in relation to their choice of onsite or online studies. As Glover and Lewis (2012) highlight, faculty members and HE administrators should evaluate whether courses can be taught online and whether student be allowed to take online courses. To clarify the possible relationships of student TPs and HE contexts, while taking preference and convenience factors into account, we present a table showing the preferences of TP profiles as 
studied in the literature, and implement our findings for differences between online and onsite contexts.

Instead of looking to demographics to paint a portrait of the online student, we believe lecturers and administration need to look at the social psychology of online students to determine which students are more likely to succeed and how to address their needs (Paloff \& Pratt, 2003). To clarify the possible relationship of student profile while taking preference and convenience factors into account, we present two tables relating TP profile in the context of convenience choice of online learning (Table 4) or the context of having the possibility to choice onsite or online HE according the learners' preferences (Table 5). Both tables include previous research evidences and implement the findings of the current study.

Table 4: Impact of the online $\mathrm{HE}$ in the context of convenience choice

\begin{tabular}{|l|l|}
\hline & Convenience choice of online learning \\
\hline Past positive & $\begin{array}{l}\text { PP are extroverts enjoying to develop social relationships. When a PP profile has to } \\
\text { enrol in an online course, he/she can fit in group-oriented courses aiming to } \\
\text { develop the social relations between the participants. }\end{array}$ \\
\hline $\begin{array}{l}\text { Past Negative } \\
\text { (PN) }\end{array}$ & $\begin{array}{l}\text { PN are introvert showing unsatisfactory interpersonal relationships in face-to-face } \\
\text { contexts but could benefit from online courses where they can be more } \\
\text { uninhibited in online interactions. }\end{array}$ \\
\hline $\begin{array}{l}\text { Present } \\
\text { Hedonist (PH) }\end{array}$ & $\begin{array}{l}\text { When personal and professional ties force a PH student to enrol in online HE } \\
\text { courses, they should look for practical rather than content-based methodologies. } \\
\text { MOOCs could be a solution for PH profiles that are forced to study online. We also } \\
\text { recommend game-based learning and collaborative elements such as forums and } \\
\text { group work courses }\end{array}$ \\
\hline $\begin{array}{l}\text { Present } \\
\text { Fatalist (PF) }\end{array}$ & $\begin{array}{l}\text { PF has been related to difficulties with ICT, and a desire for innovation and self- } \\
\text { control. PF enrolling online HE programs for convenience should benefit from ease- } \\
\text { to-use Virtual Learning Environments (VLE) and Online Educational Resources } \\
\text { (OER), such content-based on videoconferences and interactive quizzes. PF profiles } \\
\text { are better adapted to lecture-based methodologies rather than in group or } \\
\text { collaborative learning activities, where they show more difficulties and dropout } \\
\text { more often. }\end{array}$ \\
\hline $\begin{array}{l}\text { Future Time } \\
\text { Perspective } \\
\text { (FTP) }\end{array}$ & $\begin{array}{l}\text { Future oriented individuals could need to engage in online HE contexts due to the } \\
\text { need of lifelong learning, in order to advance in their career. Instructional } \\
\text { designers could use future orientation as a critical factor for promoting increased } \\
\text { proximal motivation in online students. }\end{array}$ \\
\hline
\end{tabular}


Table 5: Elements to consider for enrolling online or onsite when the learner can choose by preference

\begin{tabular}{|l|l|}
\hline & Preferences for online or onsite education \\
\hline $\begin{array}{l}\text { Past positive } \\
\text { (PP) }\end{array}$ & $\begin{array}{l}\text { Could equally attend online and onsite courses, however PP students have shown } \\
\text { preference for onsite classes in various studies because their extrovert profile } \\
\text { made them to prefer the social relations and the sense of belonging facilitated by } \\
\text { the students proximity in traditional face-to-face programs. }\end{array}$ \\
\hline $\begin{array}{l}\text { Past Negative } \\
\text { (PN) }\end{array}$ & $\begin{array}{l}\text { The PN orientation is significantly higher for online students in our sample. PN are } \\
\text { usually introvert people that can benefit from computer mediated communication } \\
\text { to uninhibited. Online education could fit their PN profile, but could probably don't } \\
\text { help them to overcome their introversion. }\end{array}$ \\
\hline $\begin{array}{l}\text { Present } \\
\text { Hedonist (PH) }\end{array}$ & $\begin{array}{l}\text { PH tend to prefer onsite classes, social interchange, and communication. However, } \\
\text { highly interactive online courses, involving active learning methodologies such } \\
\text { Game Based Learning and collaborative learning could also fit the PH seeking for } \\
\text { immediate gratification, feedback and interaction. }\end{array}$ \\
\hline $\begin{array}{l}\text { Present } \\
\text { Fatalist (PF) }\end{array}$ & $\begin{array}{l}\text { PF profiles tend to be passive, and thus could have a preference for lecture-based } \\
\text { methodologies, however, these methodologies are also found in some online } \\
\text { learning course based on lecture-based content. Our study observed that online } \\
\text { students have lower PF than onsite students. }\end{array}$ \\
\hline $\begin{array}{l}\text { Future Time } \\
\text { Perspective } \\
\text { (FTP) }\end{array}$ & $\begin{array}{l}\text { FTP students are prone to delay gratifications to achieve their goals whatever they } \\
\text { learn in onsite or online learning programs. Students with a future orientation may } \\
\text { feel more comfortable in both types of HE programs. }\end{array}$ \\
\hline
\end{tabular}

This information could help students find the best type of course based on their preferences. Institutions and teachers could also look at the relationship between student TPs and the convenience factors that could help these profiles maximise the benefits from their choice of education.

\section{Conclusions and further research}

The present study aims to understand the role of the various factors of student TPs in relation to type of course and age. The focus of this research was to look at each TP dimension separately, and therefore extend previous work, mostly focused on future and present orientations. Furthermore, we have paid attention to online HE profiles in order to better understand individual student differences when choosing an onsite or online model. Results of this study indicate that there are two variables related to the choice of an online or an onsite university model: age and temporal orientation. However, we should study the preference and convenience factors of $\mathrm{HE}$ students in order to draw a complete picture of the variables involved.

This study has shown significant differences among at least two TP factors (PP and FTP), concerning the two universities studied. These results, together with the study of age and TP, have given us an initial view of student profiles for online and onsite courses in Catalonia. Nevertheless, these two factors could be underpinning an unstudied pattern of modelling variables that demands more study. Further research with larger samples and the inclusion of other universities and a blended-model could help us further understand the tendencies observed in the present work. In particular, structural equation modelling analysis could be used to study the relationship of the variable ages, type of course, TP, and other possible differences such as prior knowledge (Volery \& Lord, 2000).

Finally, results from this study could be useful for practitioners and higher education institutions when selecting the temporal model and profiling the students attending their university. Students European Journal of Open, Distance and e-Learning - Vol. 17 / No. 1 
with a high PF factor should know in advance the constraints and demands of an online model before deciding to enrol. Older students with a part-time or full-time job and family should be informed of the difficulties posed by onsite models in adapting to their pace of study (Carnoy et al., 2012) and so help them make choices with all the available information.

\section{References}

1. Altbach, P.; Reisberg, L. and Rumbley, L. (2009). Trends in global bigher education: Tracking an academic revolution. Chestnut Hill, MA: Boston College Center for International Higher Education.

2. Artino, A.R. (2010). Internet and Higher Education Online or face-to-face learning? Exploring the personal factors that predict students' choice of instructional format. In The Internet and Higher Education, 13(4), (pp. 272-276).

3. Bates, A.T. (2004). Technology, e-learning and distance education. Routledge.

4. Bishop, M.J.; Hyclak, T. and Yerk-Zwicki, S. (2007). The clipper project: Lessons learned teaching an online economics course. In Journal of Computing in Higher Education, 18(2), (pp. 99120).

5. Boeren, E.; Nicaise, I.; Baert, H. (2010). Theoretical models of participation in adult education: The need for an integrated model. In International journal of lifelong education, 29(1), (pp. 45-61).

6. Bonk, C.J. (2009). The world is open: How web technology is revolutioniring education. Jossey-Bass

7. Bosato, G. (2001). Time perspective, academic motivation, and procrastination. Master's thesis. San Jose State University.

8. Carnoy, M.; Jarillo B.; Castano-Munoz, J.; Duart, J.M.; Sancho-Vinuesa, T. (2012). Who attends and completes virtual universities: the case of the open University of Catalonia (UOC). In Higher Education, 63, (pp. 53-82).

9. Clay, M.; Rowland, S. and Packard, A. (2009). Improving undergraduate online retention through gated advisement and redundant communication. In Journal of college student retention, 10(1), (pp. 93-102).

10. Clayton, K.; Blumberg, F. and Auld, D.P. (2010). The relationship between motivation, learning strategies and choice of environment whether traditional or including an online component. In British Journal of Educational Technology, 41(3), (pp. 349-364).

11. Cocea, M. and Weibelzahl, S. (2011). Disengagement Detection in Online Learning: Validation Studies and Perspectives. In IEEE transactions on learning technologies, 4(2), (pp. 114124).

12. Collier, C. and Morse, F.K. (2002). Requiring independent learners to collaborate: Redesign of an online course. In Journal of Interactive Online Learning, 1(1), (pp. 1-9).

13. Concannon, F.; Flynn, A. and Campbell, M.(2005). What campus-based students think about the quality and benefits of e-learning. In British Journal of Educational Technology, 36(3), (pp. 501512).

14. Costa, P. and McCrae, R. (1992). NEO personality inventory-revised (NEO PI-R). Odessa, FA: Psychological Assessment Resources.

15. Cuthrell, K. and Lyon, A. (2007). Instructional strategies: What do online students prefer? In MERLOT Journal of Online Learning and Teaching, 4, (pp. 357-362). 
16. Dabbagh, N. (2005). Pedagogical models for E-Learning: A theory-based design framework. In International Journal of Technology in Teaching and Learning, 1(1), (pp. 25-44).

17. Daugherty, M. and Funke, B.L. (2007). University faculty and student perceptions of webbased instruction. In The Journal of Distance Education, 13(1), (pp. 21-39). Retrieved from http://www.jofde.ca/index.php/jde/article/viewArticle/134

18. de Bilde, J.; Vansteenkiste, M. and Lens, W. (2011). Understanding the association between future time perspective and self-regulated learning through the lens of self-determination theory. In Learning and Instruction, 21(3), (pp. 332-344).

19. de Volder, M.L. and Lens, W. (1982). Academic Achievement and Future Time Perspective as a Cognitive-Motivational Concept. In Journal of Personality and Social Psychology, 42(3), (pp. 566-571).

20. Deal III, W. (2002). Distance Learning: Teaching technology online. In The Technology Teacher, 61, (pp. 21-26).

21. Delfino, M.; Manca, S.; Persico, D.; Sarti, L. (2004). Online Learning: Attitudes, Expectations and Prejudices of Adult Novices. In Proceedings of the LASTED Web Based Education Conference, Innsbruck, Austria, (pp. 31-36).

22. Diaz, D. (2002). As distance education comes of age, the challenge is keeping the students. In Chronicle of Higher Education, (p. A39).

23. Diaz, D.P. and Cartnal, R.B. (1999). Students' Learning Styles in Two Classes and Equivalent On-Campus. In College teaching, 47(4), (pp. 130-135).

24. Díaz-Morales, J. F. (2006). Estructura factorial y fiabilidad del Inventario de Perspectiva Temporal de Zimbardo. In Psicothema, 18(3), (pp. 565-571).

25. Eren, A. (2009). Exploring the effects of changes in future time perspective and perceived instrumentality on graded performance. In Electronic Journal of Educational Research, 19(7), (pp. 1217-1248).

26. Evans, T.N. (2009). An investigative study of factors that influence the retention rates in online programs at selected state, state-affiliated, and private universities. PhD Dissertation. UMI Number: 3388741. ProQuest.

27. Favretto, G.; Caramia, G. and Guardini, M. (2005). E-learning measurement of the learning differences between traditional lessons and online lessons. In European Journal of Open, Distance and e-Learning, 8(2). Available online at:

http:/ / www.eurodl.org/index.php?p $=$ archives\&year $=2005 \&$ halfyear $=2 \&$ article $=187$

28. Fillion, G.; Limayem, M.; Laferrière, T. and Robert, M. (2007). Integrating ICT into higher education: a study of onsite vs. online students. In Academy of Educational Leadership Journal, 11(2).

29. Fischer, G.; Rohde, M. and Wulf, W. (2007). Community-based learning: The core competency of residential, research-based universities. In Computer-Supported Collaborative Learning, 2, (pp. 9-40).

30. Fourez, M. (2009). Impoverished students' perspectives of time. ProQuest Dissertations and Theses.

31. Gallagher, J.G. (2007). Online Learning: Strategy or Sophistry? In European Journal of Open, Distance and E-Learning, 10(1). Available online at: http:/ www.eurodl.org/index.php?p $=$ archives\&year $=2007 \&$ halfyear $=1 \&$ article $=257$

32. Gibbs, G. (2003). The future of student retention in open and distance learning. In The future of open and distance learning, (pp. 37-48). 
33. Gilbert, N. (2001). Researching Social Life. SAGE.

34. Glenn, M. and D'Agostino, D. (2008). The Future of Higher Education: How Technology Will Shape Learning. New Media Consortium, 2008, October 1. ERIC Document Reproduction Service No. ED505103. Retrieved February 19, 2014, from ERIC database.

35. Glover, L. and Lewis, V. (2012). Student preference online versus traditional courses. In The Global eLearning Journal, 1(3), (pp. 1-28).

36. Green, K.C. (1996). The coming ubiquity of information technology. In Change: The Magarine of Higher Learning, 28(2), (pp. 24-28).

37. Halsne, A.M. and Gatta, L.A. (2002). Online versus Traditionally-Delivered Instruction: A Descriptive Study of Learner Characteristics in a Community College Setting. In Online Journal of Distance Learning Administration, 5(1), (p. 1).

38. Harrington, R. and Loffredo, D.A. (2010). MBTI personality type and other factors that relate to preference for online versus face-to-face instruction. In The Internet and Higher Education, 13, (pp. 89-95).

39. Hiltz, S.R.; Coppola, N.; Rotter, N.; Toroff, M.; Benbunan-Fich, R. (2000). Measuring the Importance of Collaborative Learning for the Effectiveness of ALN: A Multi-Measure. In J. Bourne (ed.), Online Education: Learning effectiveness and faculty satisfaction: Volume 1. (p. 101-119). Needham, MA.: Sloan-C.

40. Horstmanshof, L. and Zimitat, C. (2007). Future time orientation predicts academic engagement among first-year university students. In British Journal of Educational Psychology, 77(3), (pp. 703-718).

41. Hu, S.; Katherine, L. and Kuh, G.D. (2011). Student typologies in higher education. In New Directions for Institutional Research, (pp. 5-15)

42. Jacobs, J. and King, R.B. (2002). Age and college completion: A life-history analysis of women aged 15-44. In Sociology of Education, 75, (pp. 211-230).

43. Karber, D. (2003). Comparisons and contrasts in traditional versus online teaching in management. In Higher Education in Europe, 26, (pp. 533-536).

44. Kell, C. (2006). Undergraduates' learning profile development: what is happening to the men? In Medical Teacher, 28(1), (pp. 16-24).

45. Kim, T.; Welch, S.M.; Nam, S. (2012). Examining Graduate Students' Perceptions of and Preferences for Online Courses. In proceedings of Academic and Business Research Institute, International Conference - Las Vegas 2012, October 4 - 6, 2012. Available online at: http://www.aabri.com/LV2012Manuscripts/LV12065.pdf

46. Koons, K. (2012). New study - students prefer online college classes to traditional classes.

47. Lee, Y.; Choi, J. and Kim, T. (2012). Discriminating factors between completers of and dropouts from online learning courses. In British Journal of Educational Technology, 44(2), (pp. 328-337). doi:10.1111/j.1467-8535.2012.01306.x

48. Leidner, D.E. and Jarvenpaa, S.L. (1995). The use of information technology to enhance management school education: a theoretical view. In MIS Quarterly, 19(3), (pp. 265-91).

49. Lens, W.; Simons, J. and Dewitte, S. (2001). Student motivation and self-regulation as a function of future time perspective and perceived instrumentality Motivation in learning contexts: Theoretical advances and methodological implications, (pp. 233-248), Pergamon: New York.

50. MacGregor, C.J. (2000). Does personality matter? A comparison of student experiences in traditional and online classrooms. In Dissertation Abstracts International, 61, 1696A. 
51. Malka, A. and Covington, M. V. (2005). Perceiving school performance as instrumental to future attainment: effects on graded performance. In Contemporary Educational Psychology, 30(1), (pp. 60-80).

52. Mello, Z.R. and Worrell, F.C. (2006). The Relationship of Time Perspective to Age, Gender, and Academic Achievement among Academically Talented Adolescents. In Journal for the Education of the Gifted, 29(3), (pp. 271-289).

53. Miller, R.B. and Brickman, S.J. (2004). A model of future-oriented motivation and selfregulation: effects of time perspective on student motivation. In Educational Psychology Review, 16(1), (pp. 9-33).

54. Mortagy, Y. and Boghikian-Whitby, S. (2010). A longitudinal comparative study of student perceptions in online education. In Interdisciplinary Journal of E-Learning and Learning Objects, 6(1), (pp. 23-44).

55. Northrup, P. (2002). Online learners' preferences for interaction. In The Quarterly Review of Distance Education, 3(2), (pp. 219-226).

56. Oppedisano, V. (2011). The (adverse) effects of expanding higher education: Evidence from Italy. In Economics of Education Review, 30(12).

57. Paechter, M. and Maier, B. (2010). Online or face-to-face? Students' experiences and preferences in e-learning. In The Internet and Higher Education, 13(4), (pp. 292-297).

58. Palloff, R.M. and Pratt, K. (2003). The virtual student: A profile and guide to working with online learners. Jossey-Bass.

59. Paunescu, M. (2013). Students' Attitudes towards Technology-Enabled Learning: A Change in Learning Patterns? The Case of a Master's Course in Political Science. In European Journal of Open and Distance e-Learning, 16(1). Available online at:

http:/ www.eurodl.org/index.php?p=archives\&year=2013\&halfyear $=1 \&$ article $=554$

60. Peetsma, T.T.D. (2000). Future time perspective as a predictor of school investment. In Scandinavian Journal of Educational Research, 44(2), (pp. 177-192).

61. Pérez-Cereijo, M.V. (2006). Attitude as Predictor of Success in Online Training. In International Journal on E-Learning, 5(4), (pp. 623-639).

62. Robai, A.P. and Jordan, H.M. (2004). Blended Learning and Sense of Community: A Comparative Analysis with Traditional and Fully Online Graduate Courses. In International Review of Research in Open and Distance Learning, 5(2).

63. Romero, M. and Usart, M. (2012). Game Based Learning Time-on-Task and Learning Performance According to the Students' Temporal Perspective. In Proceedings of the 6 th European Conference on Games Based Learning, (pp. 4-5).

64. Romero, M. and Barberà, E. (2013). Identificación de las dificultades de regulación del tiempo de los estudiantes universitarios en formación a distancia. RED. In Revista de Educación a Distancia, 38.

65. Sangrà, A. (2001). La calidad en las experiencias virtuales de educación superior, Actas de la conferencia internacional sobre educación, formación y nuevas tecnologias, (pp. 614-625).

66. Sangrà, A. (2002). A New Learning Model for the Information and Knowledge Society: The case of the Universitat Oberta de Catalunya (UOC). In The international review of Research in Open and Distance Learning, 2(2), (pp. 1-8). 
67. Schmidt J.T. and Werner C.H. (2007). Designing Online Instruction for Success: Future Oriented Motivation and Self-Regulation. In The Electronic Journal of e-learning, 5(1), (pp. 69 78).

68. Siemens, G. and Matheos, K. (2012). Systemic changes in higher education. In Education, 16(1).

69. Simons, J.; Vansteenkiste, M.; Lens, W. and Lacante, M. (2004). Placing motivation and future time perspective theory in a temporal perspective. In Educational Psychology Review, 16(2), (pp. 121-139).

70. Sullivan, P. (2001). Gender differences and the online classroom: Male and female college students evaluate their experiences. In Community College Journal of Research \& Practice, 25(10), (pp. 805-818).

71. Sursock, A. and Smidtt, H. (2010). Trends 2010: A decade of change in European Higher Education. European University Association. ISBN: 9789078997177.

72. Swan, K.; Shea, P.; Fredericksen, E.; Pickett, A.; Pelz, W.; Maher, G. et al. (2000). Building knowledge building communities: Consistency, contact and communication in the virtual classroom. In Journal of Educational Computing Research, 23(4), (pp. 359-383).

73. Taniguchi, H. and Kaufman, G. (2005). Degree completion among nontraditional college students. In Social Science Quarterly, 86(4), (pp. 912-927).

74. Thomas, E. and Quinn, J. (2007). First generation entry into higher education. McGraw-Hill International.

75. Van der Veen, I. and Peetsma, T. (2011). Motivated for leisure in the future: A personcentred longitudinal study in the lowest level of secondary education. In Learning and Individual Differences, 21(2), (pp. 233-238).

76. Varela, O.E.; Cater, J.J. and Michel, N. (2012). Online learning in management education: an empirical study of the role of personality traits. In Journal of Computing in Higher Education, 24(3), (pp. 209-225).

77. Vermeulen, L. and Schmidt, H.G. (2008). Learning environments, learning process, academic outcomes and career success of university graduates. In Studies in Higher Education, 33(4), (pp. 431-451).

78. Volery, T. and Lord, D. (2000). Critical success factors in online education. In International Journal of Educational Management, 14(5), (pp. 216 - 223).

79. Wetterich, N.C. and Melo, M.R. (2007). Sociodemographic profile of undergraduate nursing students. In Rev Latino-am Enfermagem, 15(3), (pp. 404-410).

80. Yang, F.Y. and Tsai, C.C. (2008). Investigating university student preferences and beliefs about learning in the Web-based context. In Computers \& Education, 50(4), (pp. 1284-1303).

81. Young, A. and Norgard, C. (2006). Assessing the quality of online courses from the students' perspective. In The Internet and Higher Education, 9(2), (pp. 107-115). doi:10.1016/j.iheduc.2006.03.001

82. Yukselturk, E.; Ozekes, S. and Türel, Y.K. (2014).Predicting Dropout Student: An Application of Data Mining Methods in an Online Education Program. In European Journal of Open, Distance and E-Learning, 17(1). Available online at: http:/ /www.eurodl.org/index.php?p $=$ current\&article $=616$ 
83. Zabel, A. (1995). Correspondence course completion rates. PhD dissertation. Retrieved from https://repositories.tdl.org/ttu-ir/bitstream/handle/2346/16268/31295009342592.pdf [01/06/2014]

84. Zimbardo, P.G.; Keough, K.A. and Boyd, J.N. (1997). Present time perspective as a predictor of risky driving. In Personality and Individual Differences, 23, (pp. 1007-1023).

85. Zimbardo, P.G. and Boyd, J.N. (1999). Putting time into perspective: A valid, reliable individual differences metric. In Journal of Personality and Social Psychology, 77, (pp. 1271-1288)

86. Žuvic-Butorac, M.; Roncevic, N.; Nemcanin, D. and Nebic, Z. (2011). Blended E-Learning in Higher Education: Research on Students' Perspective. In Issues in Informing Science and Information Technology, 8, (pp. 409-429). 